\title{
United States Food and Drug Administration signals crackdown on caffeinated alcohol drinks
}

$\mathrm{T}$ he United States government has dealt what could be a death blow to caffeinated alcoholic energy drinks that federal officials said can leave people "wide-awake drunk" and more prone to risky behaviour.

The premixed caffeine-alcohol combinations - especially popular with college students and other young people - should soon be gone from US store shelves in response to warning letters that the US Food and Drug Administration sent to four manufacturers on Nov. 17, 2010, advising them that the drinks were unsafe and could be subject to seizure (www.fda.gov /Food/FoodIngredientsPackaging/ucm 190366.htm).

The FDA said the drinks, which include the popular Four Loko and Joose brands, can mask cues that tell people how drunk they are, and can result in alcohol poisoning, sexual assaults and car accidents.

Although the FDA action was not an outright ban, two of the companies that received warning letters said they expected to have all their drinks off store shelves by Dec. 13, 2010, and the other two said they were no longer producing the products. Other manufacturers were expected to quickly follow suit.

"It's definitely the death knell for caffeine in these drinks," says Michele Simon, research and policy director at the Marin Institute, a private alcohol industry watchdog group. "There's no question that the FDA has spoken loudly and clearly that caffeine is not a safe additive in alcohol."

While that may not stop young people from mixing their own caffeinealcohol concoctions, Simon says, "this is at least one way to make it less easy" for young people to get themselves in trouble with alcohol.

The amped-up combination drinks aren't available in Canada, although retailers often package caffeinated and alcoholic beverages together.

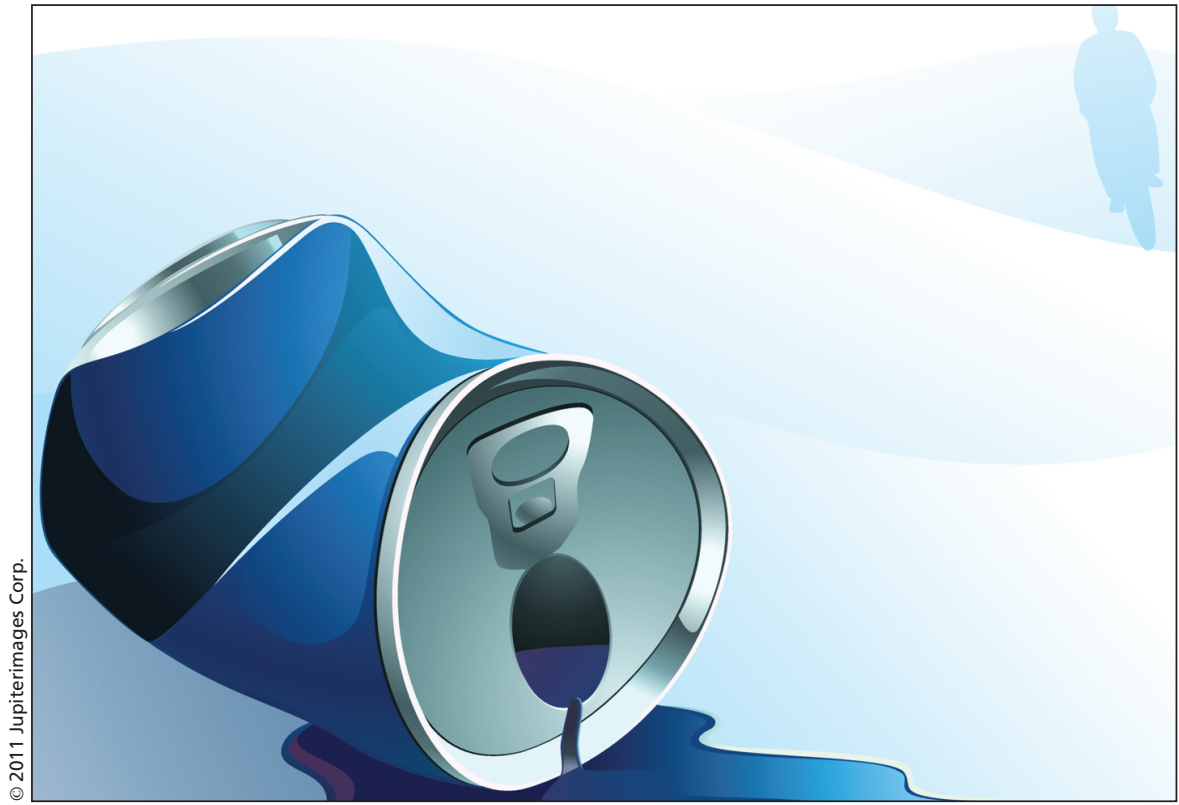

Several brands of caffeine-alcohol drinks have drawn criticism for masking a consumer's sense of inebriation.

Gary Holub, a spokesman for Health Canada, says the Canadian government sets tight controls on adding caffeine to food and drinks, and that only natural sources of caffeine are allowed in alcoholic beverages. Premixed alcoholic energy drinks are not approved for sale in Canada (www.hc -sc.gc.ca/ahc-asc/media/ftr-ati/_2010 /2010_83-eng.php).

Provincial liquor control boards can even more tightly regulate caffeine in alcoholic drinks. For example, the Liquor Control Board of Ontario allows no more than 30 milligrams of naturally occurring caffeine per serving in drinks, says spokesman Chris Layton.

With the FDA action imminent, Chicago-based Phusion Projects, which makes Four Loko, announced plans in November 2010 to reformulate the drink and market a noncaffeinated version. The company maintained that Four Loko was safe, but said it was acting "after trying - unsuccessfully — to navigate a difficult and politically-charged regulatory environment at both the state and federal levels" (www.phusionprojects .com/media_reformulation.html).

With their large, colourful cans, low cost, fruity flavors and high alcohol content, the caffeine-alcohol drinks have drawn criticism for their appeal to young people. Four Loko, for example, was marketed in 23.5-ounce cans with $12 \%$ alcohol by volume, more than twice the concentration of alcohol in regular beer. A single can could contain as much alcohol as four standard 12ounce beer cans.

When caffeine is added to the mix, the drinks "can mask a consumer's sense of intoxication," said the US Federal Trade Commission's Bruce Vladek. "As a result, consumers and particularly young, inexperienced drinkers, may not realize just how impaired they are."

The Federal Trade Commission, acting in concert with the FDA, sent letters to the same four companies warning that their marketing and sale of the drinks could constitute unfair or deceptive advertising (http://ftc.gov /opa/2010/11/alcohol.shtm). 
Before the federal government acted, at least four states moved to ban the drinks after a number of cases in which underage drinkers were hospitalized.

In 2009, a group of state attorneys general had asked the FDA to review the safety of the drinks, saying that there was an emerging consensus that the caffeine-alcohol combination "poses a serious public health threat." The attorneys general successfully pressed Anheuser-Busch and MillerCoors to halt production of caffeinated energy drinks in 2008.

Former Maine attorney general Steve Rowe, a leader in that effort, welcomed the FDA's action but says the government will have to remain vigilant to ensure the drinks aren't replaced by other unsafe concoctions or deceptive marketing practices. He noted that there are other stimulants besides caffeine.

"I hope it's the end of these, but I remain skeptical," he said.

The private Washington, DC-based Center for Science in the Public Interest said that even if caffeine is taken out of the mix, government regulators at the federal, state and local levels still have more work to do to address the marketing of high-alcohol drinks in kidfriendly flavours like watermelon and blue raspberry.

"The idea of marketing sweet alcoholic beverages to young people to get them to drink is something that should worry most parents," says David Schardt, the center's senior nutritionist. "But at least it doesn't pose the hazard that the caffeinated products did, in which kids didn't realize how much they were inebriated or impaired. We're back to a situation where young kids drink a lot."

In addition to Phusion Projects, the warning letters went to Charge Beverages Corp., maker of Core High Gravity, Core Spiked and El Jefe carbonated malt beverages; New Century Brewing Co., maker of Moonshot; and United Brands, maker of Joose. - Nancy Benac, Washington, DC

CMAJ 2011.DOI:10.1503/cmaj.109-3775 